\title{
Reciclado de Residuos de la Minería del Granito y de Incineradora de RSU en la Obtención de Nuevos Materiales Tipo Gres Porcelánico
}

\author{
Recycling of the Granite Quarries and Municipal Incinerator \\ Wastes for the Processing of New Materials as Porcelainized
}

Stoneware

Fecha de recepción: 4-X-99

Fecha de aceptación: $28-$ VII-00
M.S.HERNÁNDEZ-CRESPOYJ.Ma.RINCÓN Instituto de Ciencias de la Construcción Eduardo Torroja-CSIC

ESPAÑA

\section{RESUMEN}

Hacia la década de los años 80 se inicia en el sector cerámico la concepción del gres porcelánico, material de características modernas y versátiles semejantes a las de la piedra natural, pero que incluso supera en utilidad y prestaciones al mármol y al granito. El gres porcelánico es un material cerámico compacto, muy duro y homogéneo, no vidriado en su superficie, obtenido por cocción rápida de composiciones ricas en caolinita y una gran cantidad de fundentes; es decir, de una mezcla cerámica que contiene una relación adecuada de arcillas de tipo caolinitico, feldespatos y cuarzo. Dicho material se caracteriza por su baja o casi nula porosidad; es ideal para soportar tráfico pesado y alto tránsito, para usos en interiores y exteriores, con una variedad muy extensa de aspectos diseños y colores.

En razón de la composición química y mineralógica de los residuos de granito y de incineradoras de residuos sólidos urbanos (RSU) se planteó determinar su aprovechamiento en la obtención de materiales de construcción, especificamente, en revestimientos y pavimentos de gres porcelánico.

Los resultados han revelado la viabilidad de estos residuos en cuanto a su aprovechamiento en la obtención de nuevos materiales tipo gres porcelánico ó "Gres Porcelánico Modificado"(GPM). De acuerdo con algunas de sus propiedades, éstos se sitúan en el margen de los materiales de gres porcelánico y vitrocerámicos clásicos.

\section{SUMMARY}

In the 1980s started in the ceramic sector the material conception of porcelainized stoneware, a product with versatile and modern characteristics similar to those of the natural stone, depicting improved properties to the marble and granite. Porcelanized stoneware is a compact ceramic material, very hard and homogeneous, generally not fully vitreous (unglazed) in its surface, obtained by fast firing from compositions enriched in kaolinite, which contain a large quantity of fluxes. The raw materials for body are a mixture that contains an adequate relationship of kaolinitic clays, feldspars and quartz. Such material is characterized by its low or almost zero porosity, being adequated to sustain heavy and high traffic intensity for uses in and outside of buildings with wide range of aspects, desings and colors.

By considering the chemistry and mineralogical composition of the granite and incinerator wastes, this paper describes their use in the processing of construction materials, specifically, in a new type of stoneware flooring and covering materials.

According to the most of the physical and mechanical properties here determined, these "Modified Porcelainized Stoneware"(MPS) materials are close to the conventional porcelainized stoneware and glass ceramics products. 


\section{INTRODUCCIÓN Y OBJETIVOS}

\subsection{Gres Porcelánico}

Las plaquetas cerámicas se usan desde tiempo inmemorial como elementos en construcción o bien decorativos, como alternativa a las piedras naturales. Las de gres rústico tradicional se han usado desde tan antiguo, que no puede darse una fecha precisa de cuándo comenzó su utilización en el campo de la construcción. El desarrollo de la industria cerámica moderna, en los últimos años en Europa, se corresponde con la introducción, primero, de la doble cocción tradicional y después, del proceso de monococción rápida en hornos de rodillo. Actualmente existen en el mercado toda clase de decoraciones y colores de gres porcelánico para diferentes usos, siendo Italia el primer país del mundo productor de este tipo de materiales, cuyas características técnicas y estéticas cumplen los requisitos y normas de los clientes y del mercado. En los años más recientes estos materiales están acaparando gran interés por parte de la industria y la investigación, habiendo crecido en España su producción de manera espectacular en los últimos dos años.

El gres porcelánico es un material extremadamente duro y homogéneo y, generalmente, no vidriado. Es, además, fuertemente compacto, obtenido por cocción rápida de una mezcla cerámica en crudo prensada, que contiene una relación adecuada de arcillas de tipo caolinítico, feldespatos y cuarzo.

Como consecuencia de la composición química y mineralógica de la pasta cerámica inicial, de la finura de las materias primas y de la temperatura de cocción en el rango de $1.200-1.300^{\circ} \mathrm{C}$, la microestructura de las plaquetas cocidas se caracteriza por la presencia de çristales fuertemente enlazados de mullita y cuarzo residual, embebidos en una matriz vítrea de porosidad muy baja. La mullita $\left(3 \mathrm{Al}_{2} \mathrm{O}_{3} \cdot 2 \mathrm{SiO}_{2}\right)$ es la fase cristalina principal que se presenta en las plaquetas prensadas de esta pasta a altas temperaturas, debido a la reacción del metacaolín $\left(\mathrm{Al}_{2} \mathrm{O}_{3} \cdot 2 \mathrm{SiO}_{2}\right)$, que se forma por deshidroxilación de los materiales caoliníticos.

Gracias a su microestructura, que le confiere propiedades mecánicas y físicas peculiares, el gres porcelánico presenta resistencias excepcionalmente altas a todo tipo de tensiones, tales como desgaste por abrasión, choque térmico, alto tránsito peatonal y resistencia al impacto.

El gres porcelánico se puede utilizar con acabados superficiales, brillantes o mates, diferentes colores y combinaciones de luz, tanto para interiores, como para exteriores.

\section{INTRODUCTION AND OBJECTIVES}

\subsection{Porcelainized stoneware}

Ceramic tiles are used since time ago as elements in construction, as an alternative to the natural stones. Those materials for traditional rustic sandstone have been used in the past.

The development of modern ceramic industry, in the last years in Europe, corresponds with the introduction of the traditional double firing techniques and later by the processing of fast singlefiring in roller kills. Actually, in the market exist all type of decorations and colors of porcelainized stoneware for different uses, being Italy the first producing country of this type of materials, whose technical and aesthetic characteristics fits well the requirements and standards of the clients and the market. In the last years these materials have become a great interest in both industrial and research field. Spain has grown spectacularly its production in porcelainized stoneware along the last two years.

Porcelainized stoneware is an extremely hard, high sintered and homogeneous unglazed material obtained by fast firing from a green pressed ceramic mixture, which contains an adequate relationship of kaolinitic clays, feldspars and quartz.

As consequence of the chemical and mineralogical composition of the initial ceramic body, of the raw materials and of the firing temperature in the range 1.200-1.300 ${ }^{\circ} \mathrm{C}$, the microstructure of the fired tiles is characterized by the presence of strongly interconected crystals of mullite $\left(3 \mathrm{Al}_{2} \mathrm{O}_{3} \cdot 2 \mathrm{SiO}_{2}\right)$ and residual quartz, embedded into a glassy matrix of very low porosity. The crystallitation of mullite, which is the principal crystalline phase contained in the heat treated tiles, is due to the reaction of metakaolinite $\left(\mathrm{Al}_{2} \mathrm{O}_{3} \cdot 2 \mathrm{SiO}_{2}\right)$, formed by dehydroxylation of the kaolinitic minerals.

Due to its microstructure, which confers high mechanical and physical properties, porcelainized stoneware shows exceptionally high resistance to all type of tensions, such as wear by abrasion, thermal shock, peatonal traffic and impact resistance.

Porcelainized stoneware can be produced with a wide range of finish, such us, brilliant, dull and coloured surfaces. 
Sobre las características del producto obtenido a partir de las materias primas anteriormente citadas, procesado, propiedades físico-mecánicas y aplicaciones arquitectónicas se pueden encontrar (1, 2), así como en pastas de gres en las que se introducen determinadas cantidades de residuos (3).

\subsection{Composición de los granitos y de los residuos que genera su explotación}

Conocida la utilización del granito como materia prima feldespática para las industrias de cerámica y de vidrio (4) (5) (6), se ha considerado de gran interés el aprovechamiento de los materiales graníticos residuales de canteras y serrerías en la obtención de posibles nuevos materiales con características de gres porcelánico modificado (GPM).

La producción de piedra natural, sobre todo de naturaleza granítica, para la Construcción y Obras Públicas en algunas zonas de España, alcanza un volumen importante debido a la abundancia de materias primas de esta naturaleza. Así sucede en la Sierra del Guadarrama y en el Valle del Tiétar de la Comunidad Autonóma de Madrid (CAM), dada la gran demanda que precisa este sector en la capital y sus alrededores. Esta producción genera una importante cantidad de residuos tanto en forma de desmonte de canteras, como de material, en alto tonelaje, de cascotes de diferentes tamaños y granulometrías, y también en forma de polvo y lodos procedentes de máquinas cortadoras en los yacimientos y serrerías transformadoras de estos materiales de construcción. Los lodos se almacenan en fosos al aire libre en las proximidades de los centros de producción o elaboración.

Los granitos, según sus variedades, contienen de un $25 \%$ a un $40 \%$ de cuarzo, de un $3 \%$ a un $10 \%$ de mica, y'el resto está constituido por feldespatos de diversos tipos y por una pequeña fracción de otros minerales presentes como impurezas.

La proporción de feldespato en el granito no es nada despreciable y ya que éste interviene en la mayoría de las composiciones de materiales cerámicos y vítreos, se podría perfectamente reutilizar por este motivo el granito o sus residuos convenientemente purificados, en este tipo de industria. Los residuos de granito tienen como ventajas adicionales sobre otras materias primas naturales, el tener una composición muy constante y ser abundantes en determinadas zonas, como es el caso mencionado de la CAM.

Estos componentes fundamentales de las rocas de tipo granítico, cuarzo, feldespatos y minerales micáceos, bien por separado o combinados en pastas, se usan en la
Different authors have previouly investigated about processing, physical-mechanical properties and architectural applications of porcelainized stoneware (1) (2). The use of urban wastes in this type of products has also been investigated (3).

\subsection{Composition of wastes generated in granite quarry operations}

The use of granite as feldspatic raw materials for the ceramic and glass industries (4) (5) (6), is well known. Recently the employment of granitic wastes has been considered of great interes for the production of new materials with characteristics of modified porcelainized stoneware (MPS).

The production of natural stone, mainly of granitic nature, for the Construction and Public Works in some zones of Spain, reaches an important volume due to the abundance of raw materials. This is the case in the Guadarrama Mountains and in the Tietar river valley, both in the Autonomous Community of Madrid. This production generates an important quantity of residues in the form of crashed material, of different sizes and granulometry powder and mud wastes are also originated from the cutting machines in the deposits and sawmills.

Granitic rocks, according to their varieties, contain $25 \%-40 \%$ of quartz; $3 \%-10 \%$ of mica and the rest is constituted by diferent types of feldspars, including a small fraction of other present minerals as impurities.

The percentage of feldspar in the granite is not negligible and since this takes part in most of the ceramic and vitreous materials granite waste, could be perfectly recycled. Granite wastes have as additional advantages on other natural raw materials, to have a very constant composition and be very abundant in certain zones.

Granitic rocks have been used in the production of various ceramic materials. Thus, triaxial porcelains are formulated from ceramic pastes containing: 
producción de diversos materiales cerámicos. Así, las denominadas porcelanas triaxiales se formulan a partir de pastas cerámicas conteniendo: cuarzo, feldespato y caolín, en cuyo diagrama ternario de composición existen zonas de puntos eutécticos que permiten la formación de una abundante fase líquida (vítrea) a elevadas temperaturas, en las que se nuclean y crecen cristalizaciones fundamentalmente de mullita $\left(3 \mathrm{Al}_{2} \mathrm{O}_{3} \cdot 2 \mathrm{SiO}_{2}\right)(7)(8)$.

Como ya se ha comentado, a partir de rocas de tipo granítico, con la separación conveniente de los minerales micáceos, pueden formularse vidrios y porcelanas de tipo triaxial (4) (5) corrigiendo convenientemente su composición de partida, así como el uso de granitos para la producción de vidrio hueco (6).

Sin embargo, no se había considerado hasta más recientemente la posibilidad del uso de las rocas ígneas para la producción de vidrios con alta tendencia a la nucleación y cristalización controlada; es decir, con el fin de obtener materiales de tipo vitrocristalino o vitrocerámico por un proceso de vitrificación/ desvitrificación controlada, que puede ser especialmente útil para el reciclado y/o inertización de residuos radiactivos (9) y no-radiactivos (10) (11) (12). Dada la elevada proporción de residuos, tanto de materiales de canteras como de los polvos de serrerías en la zona centro de España, uno de los objetivos de la investigación llevada a cabo ha sido seleccionar varios de estos residuos de zonas diferentes con alta producción de granitos, para su caracterización físicoquímica, con vistas a investigar su utilización en la obtención de gres porcelánico.

\subsection{Procesos de incineración y sus residuos}

Por otro lado, a la grave problemática existente en las grandes urbes por la gran cantidad de Residuos Sólidos Urbanos (RSU) generados (en Madrid capital se cifran en $1,5 \mathrm{~kg} /$ día/habitante) se le está dando la solución más utilizada en la actualidad, su eliminación mediante procesos de incineración como está sucediendo en otras ciudades europeas, tales como: París, Birmingam, Mónaco, Viena, Bruselas, etc. Crecen, por lo tanto, el número de plantas destinadas a dichos procesos, así como uno de los mayores problemas, el acondicionamiento y almacenamiento de los residuos sólidos finales, fundamentalmente cenizas y escorias. Estos residuos de incineración se producen en grandes cantidades. Una única incineradora, por ejemplo, genera, aproximadamente, 10.000 t/año de cenizas volantes, que contienen básicamente compuestos de $\mathrm{Al}, \mathrm{Ca}, \mathrm{y} \mathrm{Si}$, además de metales pesados y trazas de contaminantes orgánicos. Debido a los quartz, feldspar and kaolin, in whose ternary composition system exist eutectic points, which allow the formation of an abundant liquid phase (vitreous) at high temperatures, which favorizes the growing of crystals, mainly of mullite $\left(3 \mathrm{Al}_{2} \mathrm{O}_{3} \cdot 2 \mathrm{SiO}_{2}\right)$ (7) (8).

As it had been commented, former papers have demostrated that granitic rocks after convenient separation of the micaceous minerals, can be used in the formulation of glasses and triaxial porcelains (4) (5) (6) by adequate composition design of starting composition.

The feasibility of igneous rocks for production of glasses with high trend to the nucleation and controlled crystallization, which can be especially advantageous for the recycling and/or inertization of radioactive (9) and non-radioactive wastes (10) (11) (12), has been also considered. Due to the high quantity of quarries producing sawmill powders in the center zone of Spain, one of the objectives of this investigation has been to characterized these residues and to formulate innovative compositions of porcelainized stoneware.

\subsection{Incineration process and its wastes}

On the other hand, the problematic existing in the large cities by the great quantity of Municipal Solid Wastes (MSW) generated (in Madrid capital are approximately $1.5 \mathrm{~kg} /$ day/ inhabitant) has given rise to their elimination through incineration process, as is usual now in other european cities, viz. Paris, Birminghan, Monaco, Vienna, Brussels, etc. Thus, the number of incinerator plants are growing, as well as the problem of management of incineration residues: ashes and slags. An urban incinerator generates, approximately, 10.000 t/year of fly ashes, which contain basically $\mathrm{Al}, \mathrm{Ca}$ and $\mathrm{Si}$ as oxide compounds, in addition to heavy metals and some traces of organic pollutants. Due to the toxic components, the 
componentes tóxicos, las cenizas volantes de incineradora están clasificadas en la mayoría de los países europeos como residuos tóxicos y peligrosos (RTP), por lo que tienen que ser depositadas en contenedores especiales que se mantienen bajo tierra, procedimiento costoso y poco satisfactorio en relación con la preservación del Medio Ambiente (13).

Ello hace muy necesario encontrar una nueva vía de inertización y/o reciclado de estos residuos sólidos. El procedimiento más beneficioso sería convertirlos en un producto industrial útil y seguro aprovechando su contenido en silicatos, para la obtención de materiales de tipo cerámico (9) (14) como es, por ejemplo, el caso del gres porcelánico.

El objetivo del trabajo ha sido también la caracterización química y mineralógica de estas cenizas, así como de los residuos de granito de la Comunidad de Madrid, para su utilización en la formulación de nuevos materiales de construcción tipo gres porcelánico, además de la determinación de las propiedades físicas y mecánicas de los materiales obtenidos.

\section{MATERIALES Y MÉTODOS}

\subsection{Caracterización de residuos y formulación de las pastas}

Las materias primas utilizadas en el estudio, como se viene comentando, han sido: una ceniza volante (CT) de una planta incineradora de residuos sólidos urbanos, (Valdemingómez, Madrid), dos lodos de granito (lodo $\mathrm{B}$ y lodo C) procedentes respectivamente de serrerías de Cadalso de los Vídrios y Cerceda, en Madrid, un feldespato y una arcilla industriales, sílice y alúmina.

Mediante análisis por vía húmeda se ha determinado la composición química de los residuos, ceniza y lodos. Los diagramas de difracción de rayos $\mathrm{X}$ se han obtenido con un difractómetro Philips PW-1730, con monocromador de grafito y radiación $\mathrm{K} \alpha \operatorname{del} \mathrm{Cu}$.

Las pastas se han formulado atendiendo a dos posibles formas de aprovechamiento de estos residuos:

a ) Conocida la composición de los lodos de granito, se corrige ésta con sílice y alúmina, hasta obtener una pasta cuya relación sílice/alúmina sea $3 / 4$, igual a la existente en una pasta de gres porcelánico estudiada previamente por otros autores (15). Las pastas así formuladas se han denominado composiciones $\mathrm{B}$ y $\mathrm{C}$ corregidas.

b) Sustitución en una composición de gres porcelánico de referencia ( $40 \%$ arcilla, $40 \%$ feldespato, $20 \%$ incinerator fly ashes are classified in most of the European countries as toxic and dangerous residues. Therefore, they must be deposited in special containers which are maintained in burial lands. This procedure is costly and not fully satisfactory in relation to the environment (13), making necessary to find a new route of inertization and/or recycling of these solid residues.

The most beneficial procedure would be to transform them into a inert and useful industrial product, taking advantage of their silicates contain for the obtention of ceramic materials (9) (14), as can be the case of the porcelainized stoneware.

Therefore, the objective of this work was also the chemical and mineralogical characterization of from incineration plant ashes, as well as the granite residues from the Autonomous Community of Madrid for their utilization in the formulation of new ceramic construction materials such as porcelainized stoneware, as well as the determination of the physical and mechanical properties of final materials.

\section{MATERIALSAND METHODS}

\subsection{Characterization of wastes and formulation of starting bodies.}

The raw materials used in this research have been: a fly ash (CT) from a MSW incinerator plant

(Valdemingómez, Madrid), two granite muds (muds $B$ and C) from two sawmills of Cadalso de los Vidrios and Cerceda, respectively, in Madrid, an industrial feldspar and clay, silica and alumina.

The chemical composition of the wastes have been determined through wet way. X-ray diffraction patterns were recorded using $C u K \alpha$ radiation in a Philips $P W$ 1730 difractometer, equipped with a graphite monochromator.

The starting composition have been formulated attending two possible ways of utilization of these residues:

a) From the composition of some granite muds the body was formulate by correcting the waste content with silica and alumina, until obtaining a paste with silical alumina $=3 / 4$, close to the existing in a porcelanized stoneware studied previously for others authors (15). These compositions were designated as corrected $B$ and C.

b) By sustitution in a porcelainized stoneware reference composition (40\% clay, $40 \%$ felspar, $20 \%$ quartz) (15) 
cuarzo) (15) de un $10 \%$ de arcilla o feldespato por lodo de granito o ceniza respectivamente. Las pastas así formuladas se han denominado composiciones $1 \mathrm{~A}$ y1F.

Las mezclas de las materias primas, para cada una de las composiciones formuladas se han homogeneizado mediante una túrbula, durante un tiempo de 10 minutos.

Las muestras de cada una de las distintas composiciones son pastillas de $20 \mathrm{~mm}$ de diámetro y 5 de espesor, obtenidas por prensado a $40 \mathrm{MPa}$. Para su cocción se colocan dichas muestras en navecillas refractarias; se someten a un ciclo de monococción en un horno programado, a una velocidad de calentamiento de $50^{\circ} \mathrm{C} /$ minuto, hasta alcanzar la temperatura prevista, permaneciendo en ésta durante 6 minutos. El descenso de la temperatura del horno tiene lugar a una velocidad también de $50^{\circ} \mathrm{C} /$ minuto, hasta llegar a temperatura ambiente.

\subsection{Diagramas de gresificación}

En los últimos años se han hecho grandes avances tecnológicos en el procesado de las baldosas cerámicas que han permitido pasar de ciclos de cocción clásicos de 14 horas, a ciclos rápidos de monococción de 40-50 minutos.

Siguiendo la misma metodología que con el gres y otros productos cerámicos (16) se han obtenido los diagramas de absorción de agua y contracción lineal, en función de la temperatura de cocción, una vez sometidas las muestras de las composiciones formuladas a ciclos de cocción de 45 minutos.

La absorción de agua (directamente relacionada con la porosidad abierta) y la contracción lineal son dos parámetros físicos fácilmente medibles y que se utilizan en la determinación de los diagramas de gresificación (sinterización) y la definición del intervalo de cocción. Los diagramas de gresificación permiten determinar el rango de cocción y el intervalo de temperaturas en el que la porosidad abierta se anula y la contracción permanece constante, lo que coincide con los valores óptimos de resistencia mecánica.

El ensayo de absorción de agua se realizó según la Norma EN 99, versión E "Baldosas cerámicas. Determinación de la absorción de agua, a partir del cual se obtienen los correspondientes diagramas de gresificación". of a $10 \%$ of clay and feldspar by granite mud and incinerator ash, respectively. The compositions were designated as $1 A$ and $1 F$.

The raw materials have been mixed and homogenized with a turbulent motion dispositiv during 10 minutes.

Bodies of $20 \mathrm{~mm}$ of diameter and $5 \mathrm{~mm}$ thickness were obtained by cold axial pressing at 40MPa. They were heat treated on refractory small tiles and submitted to a single firing cycle in a programmed furnace at heating rate of $50^{\circ} \mathrm{C} /$ minute and held at the maximun temperature during 6 minutes. The cooling rate was also at $50{ }^{\circ} \mathrm{C} /$ minute until reaching room temperature.

\subsection{Sintering curves}

In the last years there have been large advances in ceramic tile procesing, which have allowed to shorten the classic firing cycles (14 hours) to fast firing cycles of 40-50 minutes.

From previous research about porcelainized stoneware and other ceramic products (16), a study of the water absorption and linear shrinkage versus firing temperature has been made.

The water absorption (directly related to the open porosity) as well as the linear shrinkage are two physical parameters used for the drawing of the sintering graphs and definition of the firing range. Usually, these sintering curves allow to define the optimun processing conditions for obtaining the higher values of mechanical properties in the final products.

Water absortion was determined according to the UNE 99 Standar, version E "Ceramic Tiles.

Determination of water absortion". 


\subsection{Determinación de propiedades físicas y mecánicas}

La densidad de los materiales obtenidos, una vez pesados, ha sido determinada con un multipicnómetro "Quantacrome". Es un instrumento diseñado específicamente para medir el volumen real de las muestras por desplazamiento de un fluido; en este caso gas helio, recomendado por su pequeña dimensión atómica, que asegura su penetración en huecos y poros del material con la mayor exactitud.

Para determinar la microdureza $\left(\mathrm{H}_{v}\right)$ de los materiales se han realizado los ensayos correspondientes por el método de indentación Vickers, utilizando un microdurómetro modelo Matsuzawa. Se realizaron 10 indentaciones en cada muestra con la punta de diamante Vickers. Las muestras fueron sometidas a una carga de $300 \mathrm{~g}$, durante 15 segundos. Para determinar la tenacidad de fractura o constante crítica de intensidad de tensiones de fractura, $\mathrm{K}_{\mathrm{IC}}$, según la siguiente ecuación (17):

\subsection{Physical and mechanical properties}

The density of the final materials was determined by using "Quantacrome" multipycnometer. This is an instrument specifically designed to measure the true volume of the samples after a fluid desplacement; in this case the gas is helium, which is recommended since its small atomic dimension assures with maximun accuraces its penetration into crevices and porers of the material.

Vickers indentation was used to characterise the hardness $\left(H_{\checkmark}\right)$ using a high quality microhardness tester Matzusawa. The samples were submitted to ten loads of $300 \mathrm{~g}$, during $15 \mathrm{~s}$ each one. The fracture toughness, $K_{1 C}$, was calculated using the equation (17): es necesario conocer tambien el módulo de Young, E, que se ha calculado mediante indentación con punta de diamante Knoop.

\section{RESULTADOS Y DISCUSIÓN}

\subsection{Caracterización físico-química}

A partir de los análisis químicos (Tabla 1) y de difracción de rayos $\mathrm{X}$ (DRX) (Figuras 1, 2 y 3 ) se han obtenido las composiciones química y mineralógica de los residuos y materias primas utilizados.

En relación con la ceniza, se destaca en la Tabla 1 el alto contenido en $\mathrm{CaO}$ y cloruros, así como un contenido importante de sílice, alúmina y óxidos alcalinos $\left(\mathrm{Na}_{2} \mathrm{O}\right.$ y $\left.\mathrm{K}_{2} \mathrm{O}\right)$.

En cuanto a los lodos de granito se puede apreciar la naturaleza rica en álcalis de este tipo de residuos, especialmente en óxido de potasio. Los contenidos en óxido de hierro son mayores en el lodo $\mathrm{C}$, que en el $\mathrm{B}$, hecho que podría dar tal vez coloraciones no deseables para determinadas aplicaciones de los productos obtenidos con este residuo.

La ceniza es un residuo que cuenta en su composición mineralógica con variados componentes cristalinos: portlandita $\left(\mathrm{Ca}(\mathrm{OH})_{2}\right)$, calcita $\left(\mathrm{CaCO}_{3}\right)$, halita $(\mathrm{NaCl})$, silvina $(\mathrm{KCl})$, anhidrita $\left(\mathrm{CaSO}_{4}\right)$, posiblemente carbón (C), feldespato anortita, etc. Una vez lavada la ceniza
Where E is the Young's modulus, that was previously determined by means of Knoop indentation.

\section{RESULTS AND DISCUSION}

\subsection{Physico-chemical characterization}

From the chemical analysis (Table 1) and X-rays diffraction (XRD) (Figures 1, 2 and 3) the chemical and mineralogical composition of the residues and raw materials used for desing of bodies composition have been determined.

It is very clear from the ash analysis its high content in $\mathrm{CaO}$ and chloride, as well as silica, alumina and alkaline oxide.

Concerning to the granite muds it can be appreciated their enrichment in alkalis, especially in potassium oxide. The iron oxide content are greater in the $C$ than in the $B$ mud, which can give rise to colorations non adequated for some applications of the products.

The ash is a powder constituted by the following crystalline components: portlandite $\left(\mathrm{Ca}(\mathrm{OH})_{2}\right)$, calcite $\left(\mathrm{CaCO}_{3}\right)$, halite $(\mathrm{NaCl})$, silvine $(\mathrm{KCl})$, anhidrite $\left(\mathrm{CaSO}_{4}\right)$, probably coal (C), feldspar, etc. After washing this ash with water in a suspension 
TABLA 1 (TABLE 1)

Composición química (\% en peso) de los residuos y materias primas utilizados (Chemical composition (\% weight) of the wastes and raw materials used for bodies composition design)

\begin{tabular}{|c|c|c|c|c|c|}
\hline & $\begin{array}{l}\text { Ceniza } \\
\text { (Fly ash) }\end{array}$ & $\begin{array}{l}\text { Lodo B } \\
B \text { mud }\end{array}$ & $\begin{array}{l}\text { Lodo C } \\
(C \text { mud })\end{array}$ & $\begin{array}{l}\text { Arcilla } \\
\text { (Clay) }\end{array}$ & $\begin{array}{l}\text { Peldespato } \\
\text { (Feldspar) }\end{array}$ \\
\hline $\mathrm{SiO}_{2}$ & 13,10 & 74,85 & 65,20 & 64,01 & 70,21 \\
\hline $\mathrm{Al}_{2} \mathrm{O}_{3}$ & 14,00 & 13,50 & 11,85 & 31,49 & 16,53 \\
\hline $\mathrm{Fe}_{2} \mathrm{O}_{3}$ & 1,40 & 1,13 & 11,66 & 1,18 & 0,06 \\
\hline $\mathrm{CaO}$ & 62,00 & 1,02 & 2,73 & 0,25 & 0,55 \\
\hline $\mathrm{TiO}_{2}$ & -- & 0,11 & 0,12 & 0,50 & 0,05 \\
\hline $\mathrm{MnO}_{2}$ & -- & 0,05 & 0,11 & -- & --- \\
\hline $\mathrm{K}_{2} \mathrm{O}$ & 2,60 & 4,77 & 4,29 & 1,86 & 10,26 \\
\hline $\mathrm{Na}_{2} \mathrm{O}$ & 4,60 & 3,40 & 3,06 & 0,29 & 2,30 \\
\hline $\mathrm{MgO}$ & 2,40 & 0,23 & 0,31 & 0,41 & 0,06 \\
\hline $\mathrm{Cl}^{-}$ & 15,26 & - & - & --- & --- \\
\hline $\mathrm{P}_{2} \mathrm{O}_{5}$ & -- & 0,05 & 0,22 & --- & -- \\
\hline
\end{tabular}



Figura 1.- Análisis por DRX de la ceniza CT: a) procedente de la planta incineradora; b) lavada con agua a ebullición. P: portlandita; $Q$ : cuarzo; $A n$ : anortita; Anh: anhidrita; +: calcita; $\bullet$ : halita; $\mathbf{0}$ : silvina; Ca: cal libre; C: carbón.

Figure 1.- Analysis by XRD of the fly ash: a) from the incinerator plant; b) after washing with boiling water. P: portlandite; Q: quartz; An: anorthite; Anh: anhidrite; +: calcite; $\bullet$ : halite; O: silvine; Ca:free lime; C: free coal.



Figura 2.- Análisis por DRX de los lodos: a) lodo B; b) lodo C. I: illita; O ortosa; Q: cuarzo; A: albita; +: calcita; Sp: espinela.

Figure 2.- Analysis by XRD of the muds: a) B mud; b) C mud. I: illite; $O$ : orthoclase; Q: quartz; A: albite; +: calcite; Sp: spinel.

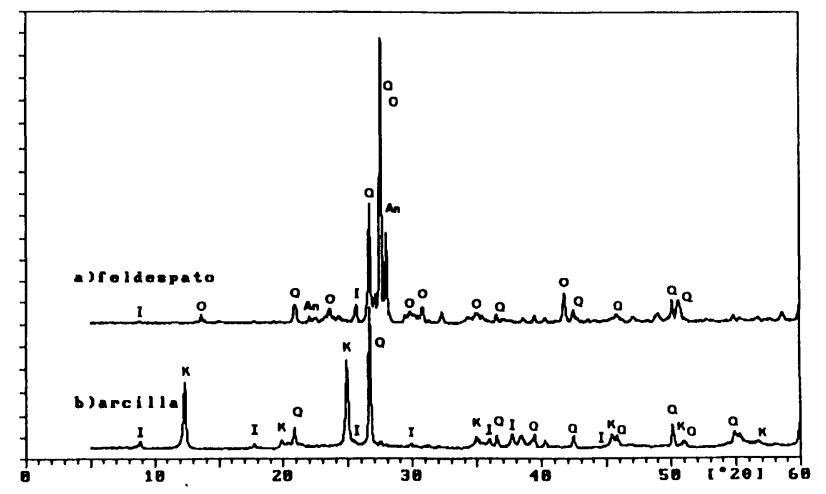

Figura 3.- Análisis por DRX de las materias primas: a) feldespato; b) arcilla. I: illita; O: ortosa; Q: cuarzo; An: anortita; K: caolinita Figure 3.- Analysis by XRD of the raw materials: a) feldspar; b) clay. I: illite; O: orthoclase; Q: quartz; An: anorthite; K: kaolinite. 
con agua en suspensión durante 24 horas, se ha observado en el diagrama correspondiente (Figura 1b) la desaparición de una línea muy diferenciada a $8,3 \AA$ de un compuesto que no se ha podido identificar, lo que indica que se debe a un compuesto soluble, o bien, a una fase de cuarzo de un tamaño de partícula capaz de pasar a través del papel de filtro. Coincide esta reflexión con la de un tipo de sílice micronizada. Las difracciones, que corresponden a sales solubles, como $\mathrm{NaCl}$ y $\mathrm{KCl}$ desaparecen o disminuyen de intensidad en el diagrama, cuando la ceniza se somete a un lavado en medio acuoso.

En los diagramas de rayos $\mathrm{X}$ correspondientes a los lodos (Figura 2), se observa, como era de esperar, la presencia de $\alpha$-cuarzo, albita y ortosa como minerales mayoritarios, además se detectan tambien minerales micáceos y una pequeña proporción de magnetita ( $\mathrm{y} / \mathrm{o}$ espinelas), debido al arrastre de partículas metálicas de los útiles de corte, así como algo de calcita.

Los análisis mineralógicos de la arcilla y del feldespato empleados en la formulación de las pastas de gres se recogen en la Figura 3. Se observa que se trata de una arcilla rica en caolinita $\left(\mathrm{Al}_{2} \mathrm{O}_{3} \cdot 2 \mathrm{SiO}_{2}\right.$. $2 \mathrm{H}_{2} \mathrm{O}$ ), conteniendo además una cantidad considerable de cuarzo y minerales micáceos (illitas). Esta arcilla, usada normalmente en la fabricación de soportes de pavimentos, presenta además una pequeña proporción de feldespato ortosa. El feldespato usado como componente de las pastas de gres es fundamentalmente del tipo ortoclasa, incluyendo también feldespato de plagioclasa (anortita) y algo de minerales micáceos (illita) como impurezas. La composición química de las pastas ensayadas se presenta en la Tabla 2. during 24 hours, it has been observed from the corresponding XRD pattern (Figure 1b) the disappearance of the $8.3 \mathrm{~A}$ diffracction. This is due to an extremely low or soluble compound capable of being removed through the paper filter. In principle, this reflection is very close to a form of microcrystalline silica. The diffraction patterns, that correspond to soluble salts, as $\mathrm{NaCl}$ and $\mathrm{KCl}$ disappear or reduce their intensity, when the ash is submitted to a washing in aqueous media.

From the corresponding XRD graphs of the muds (Figure 2), it can be concluded, the presence of $\alpha$-quartz, albite and orthoclase as main mineral phases. Furthermore, are also detected micaceous minerals and a small proportion of magnetite (and/or spinels), which are due to the metallic particles, as well as some of calcite coming from the cutting process.

The mineralogic analysis of clay and feldspar used in the formulation of the porcelainized stoneware samples are collected in the Figure 3. The clay is highly enriched in kaolinite $\left(\mathrm{Al}_{2} \mathrm{O}_{3} \cdot 2 \mathrm{SiO}_{2} \cdot 2 \mathrm{H}_{2} \mathrm{O}\right)$ containing a considerable quantity of quartz and micaceous mineral (illites). This clay, which is normally used in the manufacture of substrates for tiles also shows a small proportion of orthoclase. The feldspar is basically orthoclase type including plagioclase feldspar (anorthite) and micaceous minerals (illite) as impurities. The chemical composition of the tested bodies is showed in Table 2.

TABLA 2 (TABLE 2)

Composición química de las pastas ensayadas

(Chemical composition of the tested bodies)

\begin{tabular}{|c|c|c|c|c|c|}
\hline $\begin{array}{c}\% \\
\text { peso } \\
\text { (weight) }\end{array}$ & $\mathrm{R}$ & B & C & $1 \mathrm{~A}$ & IF \\
\hline $\mathrm{SiO}_{2}$ & 73,54 & 69,65 & 61,54 & 74,71 & 66,85 \\
\hline $\mathrm{Al}_{2} \mathrm{O}_{3}$ & 19,28 & 20,48 & 18,09 & 17,50 & 18,76 \\
\hline $\mathrm{Fe}_{2} \mathrm{O}_{3}$ & 0,50 & 1,01 & 10,58 & 0,49 & 0,62 \\
\hline $\mathrm{CaO}$ & 0,36 & 0,92 & 2,44 & 0,44 & 6,42 \\
\hline $\mathrm{TiO}_{2}$ & 0,23 & 0,09 & 0,09 & 0,19 & 0,22 \\
\hline $\mathrm{MnO}_{2}$ & --- & 0,05 & 0,1 & --- & --- \\
\hline $\mathrm{K}_{2} \mathrm{O}$ & 4,85 & 4,43 & 3,81 & 5,14 & 4,02 \\
\hline $\mathrm{Na}_{2} \mathrm{O}$ & 1,03 & 3,14 & 2,74 & 1,35 & 1,25 \\
\hline $\mathrm{MgO}$ & 0,19 & 0,18 & 0,28 & 0,17 & 0,35 \\
\hline $\mathrm{Cl}^{-}$ & --- & --- & --- & --- & 1,51 \\
\hline $\mathrm{P}_{2} \mathrm{O}_{5}$ & --- & 0,05 & 0,20 & --- & --- \\
\hline TOTAL & 99,98 & 100 & 99,91 & 99,99 & 100 \\
\hline
\end{tabular}


Las Figuras 4-7 muestran los diagramas de gresificación obtenidos para las composiciones $\mathrm{B}$ y C, que corresponden a los lodos corregidos, y para las composiciones $1 \mathrm{~A}$ y $1 \mathrm{~F}$, en las que se realizó la sustitución en un gres triaxial de parte de la arcilla por lodo o del feldespato por ceniza, respectivamente.

En dichos diagramas o curvas de gresificación se aprecia cómo varía la absorción de agua del material, así como la contracción lineal en función de la temperatura de cocción. Se puede observar, en general, que en estas pastas al aumentar la temperatura, disminuye la porosidad abierta (de la que depende la capacidad del material para absorber agua) y aumenta la contracción lineal hasta llegar a valores máximos en que ésta se estabiliza, disminuyendo a más altas temperaturas por reblandecimiento parcial del material. La porosidad disminuye progresivamente haciéndose prácticamente nula a una determinada temperatura, dependiendo del tipo de residuo y de la composición de la pasta. La evolución que siguen tanto la contracción lineal, como la absorción de agua, en términos generales, es la que cabe esperar en la sinterización de un producto cerámico por influencia de la formación de una fase vítrea o "líquido transitorio”, que favorece la sinterización. En las pastas de gres porcelánico la viscosidad del sistema no experimenta una disminución normal con la temperatura. Ésta se reduce por la formación de mullita $\left(3 \mathrm{Al}_{2} \mathrm{O}_{3} \cdot 2 \mathrm{SiO}_{2}\right)$ y la disolución del cuarzo, lo que contribuye a aumentar el rango de cocción de estos productos (1).

Los lodos corregidos, B y C, presentan su máxima contracción lineal y mínimos valores de absorción de agua, cerca de los $1.200^{\circ} \mathrm{C}$, siendo el lodo $\mathrm{C}$ el que da lugar a menores valores de absorción. Por otra parte, las pastas de gres sinterizan a mayores temperaturas, desde $1.250^{\circ} \mathrm{C}$ en el caso de la muestra $1 \mathrm{~F}$ y $1.300^{\circ} \mathrm{C}$ en el caso de la 1A. En cuanto a los valores de contracción, éstos son menores que cuando se sinterizan sólo los lodos (Figuras 4 y 5), con lo que, tanto la adición unilateral de lodo, como de ceniza en

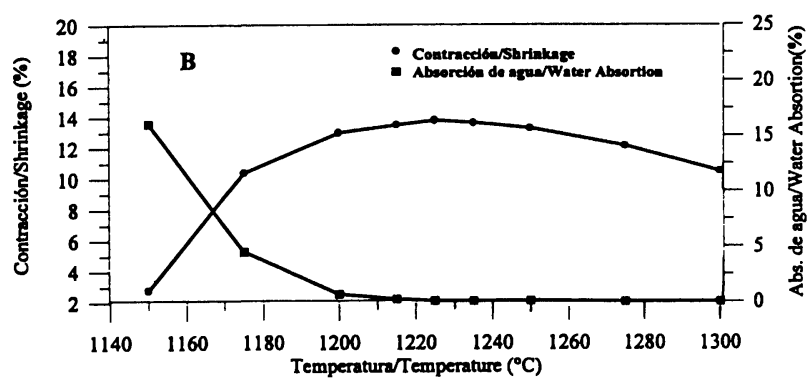

Figura 4.- Diagramas de gresificación de la composición B.

Figure 4.- Sintering curves of the B composition.
The Figures 4-7 show the sintering curves obtained for $B$ and $C$ compositions, which correspond to the corrected muds, and for $1 \mathrm{~A}$ and $1 \mathrm{~F}$ compositions, which are formulated by substituting in a triaxial porcelain the quartz and feldspar by granite mud and fly ash, respectively.

The sintering curves show the variation of the water absortion, as well as the linear shrinkage versus the firing temperature. It can be seen from their open porosity, in general, that these bodies upon increasing the temperature, decrease the open porosity (considered as the capacity of material for absorbing of water) and increases the linear shrinkage until reaching a maximum value which is later stabilized. The porosity is reduced progressively being practically null to a given temperature, depending on the waste type and on the composition of the original body. The evolution of the linear shrinkage, as well as of the water absorption, fits well with the sintering process of a ceramic products and it is affected by the formation of a vitreous phase or "transitory liquid", which improves this sintering process. In the porcelainized stoneware bodies the viscosity of the system does not suffer a normal decrease with temperature. This is reduced by the formation of mullite $\left(3 \mathrm{Al}_{2} \mathrm{O}_{3} \cdot 2 \mathrm{SiO}{ }_{2}\right)$ and the dissolution of the quartz, which contributes to the increasement of the firing process of these products (1).

The corrected compositions of the $B$ and $C$ muds, show their maximum linear shrinkage and minimum water absorption values at about $1.200^{\circ} \mathrm{C}$, being the $C$ mud the one which depicts smaller absorption values. On the other hand, the bodies of porcelanized stoneware have been sintered at $1.250^{\circ} \mathrm{C}$ in the case of $\mathrm{IF}$ and at $1.300^{\circ} \mathrm{C}$ in the case of $1 \mathrm{~A}$ samples. Concerning the shrinkage values, these are smaller than sintered muds (Figures 4 y 5). In any case, it has been proved that the unilateral addition of ash and granite mud to a

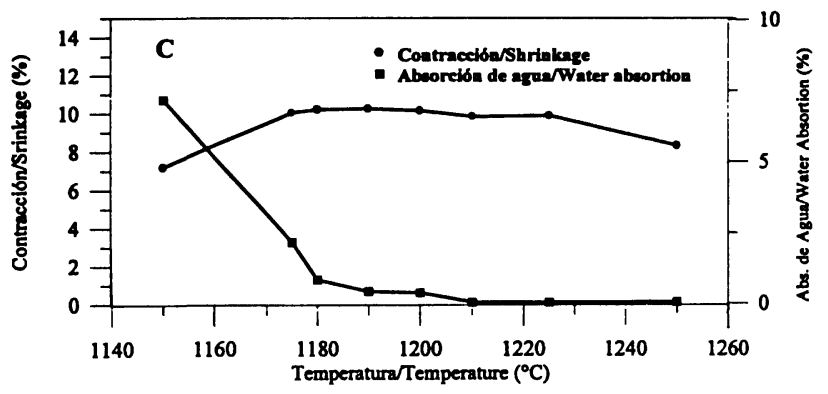

Figura 5.- Diagramas de gresificación de la composición C.

Figure 5.- Sintering curves of the $C$ composition. 




Figura 6.- Diagramas de gresificación de la composición 1A.

Figure 6.- Sintering curves of the IA composition.

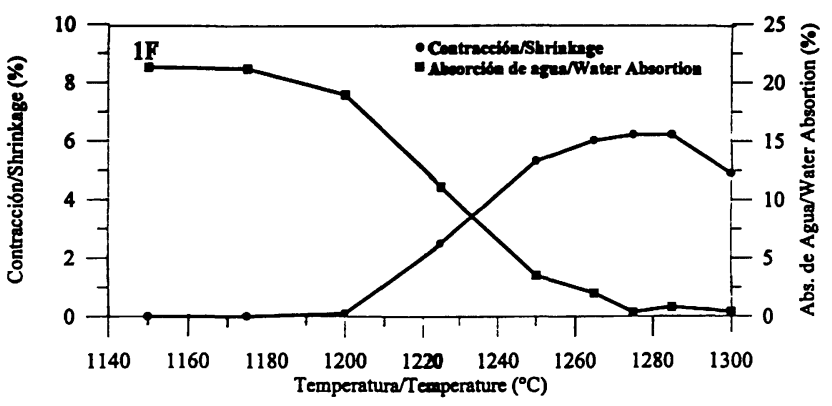

Figura 7.- Diagramas de gresificación de la composición $1 \mathrm{~F}$.

Figure 7.- Sintering curves of the IF composition.

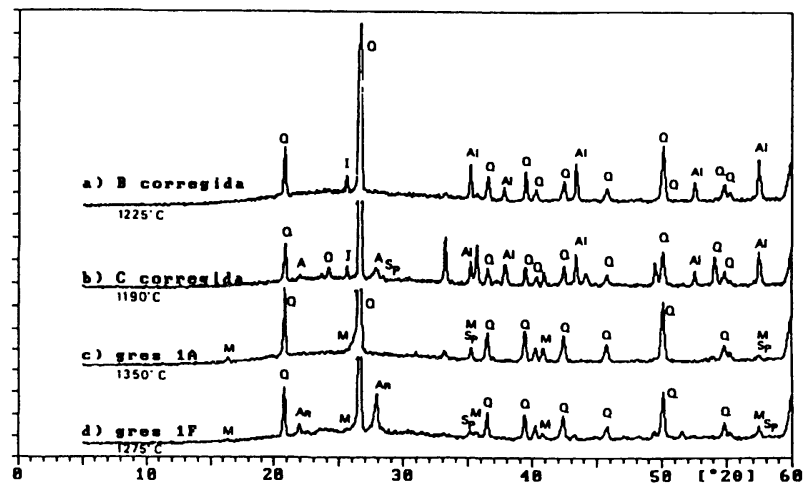

Figura 8.- Diagramas de DRX de las muestras en las que la temperatura de cocción da lugar a valores mínimos de absorción de agua: a) pasta $\mathrm{B}$ corregida $\left(1.225^{\circ} \mathrm{C}\right)$; b) pasta $\mathrm{C}$ corregida $\left(1.190^{\circ} \mathrm{C}\right)$; c) pasta de gres $1 \mathrm{~A}$ $\left.\left(1.350^{\circ} \mathrm{C}\right) \mathrm{yd}\right)$ pasta de gres $1 \mathrm{~F}\left(1.275^{\circ} \mathrm{C}\right) . \mathrm{M}$ : mullita; $\mathrm{Q}$ : cuarzo; Al: alúmina; I: Illita; An: anortita; Sp: espinela.

Figure 8.- DRX diagrams of the samples corresponding to the firing temperature which gives rise to minimal absorption values of water: a) corrected composition $B\left(1.225{ }^{\circ} \mathrm{C}\right)$; b) corrected composition $C$ $\left(1.190^{\circ} \mathrm{C}\right)$; c) porcelanized stoneware $1 \mathrm{~A}\left(1.350^{\circ} \mathrm{C}\right)$ and d) porcelanized stoneware IF $\left(1.275^{\circ} \mathrm{C}\right)$. M: mullite; Q: quartz; Al: alumina; I: Illite; An: anortite; Sp: spinel.

una pasta de gres convencional, supone una mejora en el proceso de sinterización. Este efecto es mayor en cuanto a los valores de absorción de agua, que en cuanto a los valores de contracción lineal obtenidos.

El comportamiento de sinterización está intimamente relacionado con las fases minerales, que se forman durante la cocción. Así, en los materiales obtenidos por cocción rápida, que presentan el menor porcentaje de absorción de agua y cuya contracción es máxima, se han identificado las fases cristalinas de las muestras cocidas a las temperaturas correspondientes (Figuras 8, a-d)

Se comprueba que los productos de cocción de los lodos corregidos B y C, a temperatura de $1.225^{\circ} \mathrm{C}$ y $1.190^{\circ} \mathrm{C}$ respectivamente, están constituidos por cuarzo y restos de minerales micáceos originales del granito, así como de alúmina residual. En el lodo conventional paste implies an improvement of the sintering process; more concerning to the values of water absorption, than the obtained linear shrinkage values.

The sintering behavior is closely related to the mineral phases formed during the firing process. Thus, the materials obtained by fast firing show the smaller percentage of water and maximum shrinkage. BY XRD it has been detected the crystalline phases of the fired samples at the corresponding temperatures (Figures 8, a-d).

Therefore, it has been demostrated that the firing products of the corrected $B$ and $C$ muds, at temperatures of $1.225^{\circ} \mathrm{C}$ and $1.190{ }^{\circ} \mathrm{C}$ respectively, are constituted by quartz and a small percentage of the mica minerals coming from the granite waste. In the B mud the feldspar 
$\mathrm{B}$ el componente feldespático ha fundido, mientras que en el lodo $\mathrm{C}$ parece ser que queda a $1.190^{\circ} \mathrm{C}$ algo de feldespato residual (albita y ortosa). En este lodo además se forman fases que contienen óxidos de hierro, tales como hematites y espinelas. Por otro lado, en las pastas de gres en las que se ha sustituido la arcilla y el feldespato por lodo y ceniza (Figuras 8,c-d) se forma mullita, de una manera incipiente en ambos casos, a 1.350 y $1.275^{\circ} \mathrm{C}$, respectivamente. Esta fase apenas se detecta por DRX, lo que indica que se trata de una mullita primaria o que su fracción y tamaño es sumamente pequeño. Las observaciones por microscopía electrónica que están en curso, permitirán la localización e identificación de dicha fase.

Debido a que en este nuevo tipo de materiales de "gres porcelánico modificado" (GPM) se identifican algunas reflexiones de baja intensidad de espinela (ó $\gamma$-alúmina) se confirma que la mullita no se ha desarrollado suficientemente.

Por último, en el caso del gres de composición 1F, obtenido sustituyendo feldespato por ceniza de incineradora, cristaliza anortita junto con dicha mullita incipiente o mullita primaria.

\subsection{Propiedades físico-mecánicas}

Las propiedades determinadas en estos nuevos materiales, obtenidos a partir de granito y residuos de incineradora, han sido la densidad y las propiedades mecánicas (Tabla 3).

Con respecto a los valores de densidad de las muestras que presentan valores bajos de absorción de agua y máximos de contracción lineal, éstos están en el rango de $2,13-2,73 \mathrm{~kg} / \mathrm{dm}^{3}$, siendo, en general, muy similares a los del gres porcelánico clásico (1).

Las propiedades mecánicas obtenidas por métodos de indentación han sido: microdureza Vickers $\left(\mathrm{H}_{v}\right)$, módulo de Young (E) y Factor Crítico de Intensidad de component has melted, while in the $C$ mud it seems that at $1.190{ }^{\circ} \mathrm{C}$ stays a rest of feldspar (albite and orthoclase). Furthermore, in this mud some phases containing iron oxides, such as hematite and spinel are formed. On the other hand, in the bodies in which composition different percentages of clay and feldspar have been substituted by mud and ash (Figures 8, cy d) mullite has been formed, but in a very small quantity or with a very incipient crystalline character at $1.350{ }^{\circ} \mathrm{C}$ and $1.275^{\circ} \mathrm{C}$, respectively. This phase is hardly detected by XRD, what indicates that can be considered as a primary mullite or that their volume fraction and size is extremely small. Observations by scanning electron microscopy (SEM), now in progress, will allow the location and the identification of such phase.

Even more, due to the fact that in these "modified porcelainized stoneware materials" (MPS) are identified some reflections of spinel (or $\gamma$-alumina), it is confirmed that this mullite has not been sufficiently developed.

Finally, in the case of the $1 F$ composition, obtained by: substitution of feldspar by incinerator ash, it has been proved the formation of anorthite crystals jointly with the incipient or primary mullite.

\subsection{Physical and mechanical properties}

So far the properties determined in these new materials obtained from granite and incinerator wastes have been density and mechanical properties (Table 3).

With respect to the density values of samples showing lower values of water absorption and maximum linear shrinkage they are in the $2.13-2.73 \mathrm{~kg} / \mathrm{dm}^{3}$ range. These density values are, in general, very close to the commercial porcelainized stoneware (1).

The mechanical properties by indentation methods, here determined, were: Vickers microhardness ( $H_{\downarrow}$ ), Young Modulus (E) and Stress Intensity Factor or Toughness

TABLA 3

Propiedades mecánicas y densidad

TABLE 3

Mechanical properties and density

\begin{tabular}{|c|c|c|c|c|}
\hline $\begin{array}{c}\text { Muestra } \\
\text { (Sample) }\end{array}$ & $\mathrm{H}_{\mathrm{v}}(\mathrm{GPa})$ & $\mathrm{E}(\mathrm{GPa})$ & $\mathrm{K}_{\mathrm{lC}}\left(\mathrm{MPam}^{\mathrm{i}}\right)$ & $\rho\left(\mathrm{kg} / \mathrm{dm}^{3}\right)$ \\
\hline $\mathrm{B}-1.225^{\circ} \mathrm{C}$ & 6,3 & 106 & 1,7 & 2,28 \\
$\mathrm{C}-1.190^{\circ} \mathrm{C}$ & 6,4 & 227 & 2,5 & 2,73 \\
$1 \mathrm{~A}-1.350^{\circ} \mathrm{C}$ & 6,7 & 152 & 2,3 & 2,24 \\
$1 \mathrm{~F}-1.275^{\circ} \mathrm{C}$ & 6,1 & 106 & 1,6 & 2,13 \\
\hline
\end{tabular}


Tensiones $\left(\mathrm{K}_{\mathrm{IC}}\right)$ que están en el intervalo o dan valores mayores que los de materiales similares usados como pavimentos:

Los valores de $\mathrm{H}_{\mathrm{v}}$, entre 6,1-6,7 GPa, son muy próximos a los del gres porcelánico convencional (1). El módulo de elasticidad, E, está en el intervalo de 106-227 GPa, mostrándose muy alto el valor para el material $\mathrm{C}\left(1.190^{\circ} \mathrm{C}\right)$ y en el rango de valores que corresponden a productos vitrocerámicos (10).

Los resultados más interesantes en el caso de la tenacidad de fractura, $\mathrm{K}_{\mathrm{IC}}$, han sido obtenidos para los materiales $\mathrm{C}\left(1.190^{\circ} \mathrm{C}\right)$ y $\mathrm{A}\left(1.350^{\circ} \mathrm{C}\right)$ con valores de 2,5 y 2,3 $\mathrm{MPam}^{1 / 2}$. Éstos son más altos que los correspondientes al gres porcelánico y los vitrocerámicos clásicos. Dichos valores para otros materiales aquí investigados,

$\mathrm{B}\left(1.225^{\circ} \mathrm{C}\right)$ y $1 \mathrm{~F}\left(1.275^{\circ} \mathrm{C}\right)$, están en el intervalo de los correspondientes a la mullita (18).

Esta investigación está ahora en progreso para determinar otras propiedades físicas y químicas y definir mejor la relación entre la microestructura y propiedades mecánicas de los materiales obtenidos, que podrían tener aplicaciones como pavimentos y revestimientos en la Construcción a la vista de los primeros resultados que aquí se presentan.

\section{CONCLUSIONES}

Los valores de densidad de los materiales obtenidos están en el rango de $2,13-2,73 \mathrm{~kg} / \mathrm{dm}^{3}$, siendo muy similares a los del gres porcelánico convencional.

Las propiedades mecánicas determinadas por métodos de indentación: microdureza Vickers $\left(\mathrm{H}_{\mathrm{y}}\right)$, módulo de Young (E) y factor crítico de intensidad de tensiones $\left(\mathrm{K}_{\mathrm{IC}}\right)$ están en el rango o dan valores mayores que los de materiales similares usados como pavimentos.

- Los valores de $\mathrm{H}_{\mathrm{v}}$ obtenidos, entre 6,1-6,7 GPa, son muy próximos a los del gres porcelánico clásico. - Los valores del módulo de elasticidad están en el rango de 106-227 GPa, mostrándose muy alto el correspondiente al material $\mathrm{C}\left(1.190^{\circ} \mathrm{C}\right)$ y en el margen de los que corresponden a productos vitrocerámicos.

- Los resultados más interesantes en el caso de $\mathrm{K}_{\mathrm{IC}}$ han sido obtenidos para los materiales $\mathrm{C}\left(1.190^{\circ} \mathrm{C}\right)$ y $1 \mathrm{~A}$ $\left(1.350^{\circ} \mathrm{C}\right)$, con valores de 2,5 y $2,3 \mathrm{MPam}^{1 / 2}$, respectivamente. Estos valores son superiores a los obtenidos para el gres porcelánico y los vitrocerámicos clásicos; en el caso de los materiales $\mathrm{B}$ $\left(1.225^{\circ} \mathrm{C}\right)$ y $1 \mathrm{~F}\left(1.275^{\circ} \mathrm{C}\right)$, los valores están en el margen de los correspondientes a la mullita.
$\left(K_{I C}\right)$ which are in the range and/or higher of similar materials used as pavements (Table 3).

The $H_{v}$ values are in the 6.1-6.7 GPa range, being very close to porcelainized stoneware. Elasticity modulus is between 106-227 GPa, being very high the value for the $C\left(1.190^{\circ} \mathrm{C}\right)$ material and ranging in the glass-ceramics products (10).

The most interesting results in the case of $K_{I C}$ has been obtained for the $C\left(1.190^{\circ} \mathrm{C}\right)$ and $1 A\left(1.350{ }^{\circ} \mathrm{C}\right)$ materials with values of 2.5 and $2.3 \mathrm{MPam}^{1 / 2}$, respectively. These values are higher than those corresponding to the porlainized stoneware and conventional glass ceramics. Values obtained for others materials here investigated $(B$ and $I F)$ are in the range of the mullite values (18).

This research is now in progress in order to determine the chemical and other physical properties and better definition of relationships between microstructure and mechanical properties of the final products, which could have some applications as flooring and covering materials.

\section{CONCLUSIONS}

With respect to the density values of the final products they are in the $2.13-2.73 \mathrm{~kg} / \mathrm{dm}^{3}$ range, very close, in general, to the commercial porcelainized stoneware values.

The mechanical properties by indentation methods, here determined, were: Vickers microhardness $\left(H_{\checkmark}\right)$, Young Modulus (E) and Stress Intensity Factor or Toughness $\left(K_{l O}\right)$ which are in the range and/or higher of similar materials used as pavements.

- The $H_{\mathrm{v}}$ values are in the 6.1-6.7 GPa range, being very close to porcelainized stoneware.

- Elasticity modulus is between 106-227 GPa, being very high the value for the $C\left(1.190^{\circ} \mathrm{C}\right)$ material and ranging in the glass-ceramics products

- The most interesting results in the case of $K_{1 C}$ has been obtained for the $C\left(1.190{ }^{\circ} \mathrm{C}\right)$ and $1 \mathrm{~A}\left(1.350^{\circ} \mathrm{C}\right)$ materials, with values of 2.5 and $2.3 \mathrm{MPam}^{1 / 2}$. These values are higher than those corresponding to the porcelainized stoneware and conventional glass ceramics. Values obtained for others materials here investigated $B\left(1.225^{\circ} \mathrm{C}\right)$ and $\mathrm{F}\left(1.275^{\circ} \mathrm{C}\right)$ are in the range of the mullite values. 
Con los resultados obtenidos en esta investigación se estaría ante una nueva familia de materiales de "Gres Porcelánico Modificado" (GPM) con prometedoras aplicaciones en la Construcción.

\section{AGRADECIMIENTOS}

Los autores quieren agradecer a la Comunidad Autónoma de Madrid (CAM) la financiación del proyecto $n^{\circ} 06 \mathrm{M} / 028 / 96$ a cargo del cual se ha realizado este trabajo dentro de un Programa de Investigación en Medio Ambiente, a las empresas Euroarce (Castellón) y Mario Pilato Blat (Valencia) el haberles facilitado las materias primas utilizadas (feldespato, arcilla y sílice), así como los análisis químicos correspondientes y a la Dra. M. Romero y a Dña. P. Díaz del Grupo/Lab. de Materiales VitroCerámicos del IETcc, CSIC la ayuda prestada.
According to the results here obtained, the final materials could be a new type of stoneware, "Modified Porcelainized Stoneware"(MPS), with promissing applications in construccion field.

\section{ACKNOWLEDGEMENTS}

The authors gratefully acknowledge to the Autonomous Community of Madrid the financial support in a Environment Research Programme, Proyect $n^{\circ}$ 06M/028/96; to Euroarce (Castellón) and Mario Pilato Blat (Valencia) companies the used raw materials and their corresponding chemical analyses and, finally, to Dra. M. Romero and P. Diaz from The Glass-Ceramics Lab./Group, IETcc, CSIC their valuable assistance.

\section{BIBLIOGRAFÍA}

(1) T. Manfredini, M. Romagnoli, J.Ma. Rincón, Gres porcelánico: aplicaciones arquitectónicas, procesado y propiedades fisicomecánicas. Materiales de Construcción, Vol. 46, n² 242-243 (1996), pp. 107-117.

(2) G. Biffi, Fine porcelain stoneware tiles. Editoriale Faenza editrice s. p. a. (1992)

(3) F.Andreola, L. Barbieri, I. Lancellotti, F. Mauridis, P. Pozzi, Utilizzo di scorie da incineratore urbano nella produzione di gres porcellanato, RS Rifiuti Solidi, Vol. 12, nº 3(1998), pp.174-178.

(4) A. García-Verduch, J. Requena, El granito como materia prima feldespática para las industrias de cerámica y vidrio (I), Técnica Cerámica, Vol. 237(1995), pp. 616-628.

(5) A. García-Verduch, J. Requena, El granito como materia prima feldespática para las industrias de cerámica y vidrio (II), Técnica Cerámica, Vol. 238(1995), 697-710.

(6) J. Requena, Utilización del granito en la obtención de vidrio y materiales cerámicos, Tesis Doctoral, Univ. Complutense, Madrid (1975).

(7) A. García-Verduch, J.M. García Alvarez, F.J. Gomis Noguera, Microestructura de una porcelana triaxial, Bol. Soc. Esp. Ceram. Vidr., Vol. 6, nº1 (1967), pp.43-65.

(8) W.D. Kingery, H.K. Bowen, D.R. Uhlmann. Introduction of Ceramics. Edit. John Wiley \& Sons, New York, Chichester, Brisbane, Toronto, Singapore $2^{\mathrm{a}} \operatorname{Edit}(1976)$

(9) M. Hidalgo, J. Ma. Rincón, Fundamentos de la inmovilización de residuos radiactivos en matrices vítreas y vitrocerámicas, Bol. Soc. Esp. Ceram. Vidr., Vol. 26, nº 4(1987), pp. 227-234.

(10) T. Manfredini, G.C. Pellacani, J.Ma. Rincón, Glass-Ceramic Materials. Fundamentals and Aplications, Edit Mucchi eds., Módena, Italia(1997).

(11) J. Ma. Rincón, M. Romero, Aplicaciones en la producción de materiales vitrocerámicos de residuos minerales de canteras y serrerias de granito. Geogaceta, Vol. 20 (1996), pp. 1552-1553.

(12) L. Barbieri, I. Lancelloti, T. Manfredini, I. Queralt, J. Ma. Rincón, M. Romero, Design, Obtainment and Properties of Glasses and Glass-Ceramics from Coal flyash, Fuel, Vol. 78 (1999), pp. 271-276.

(13) IDAE Miner, Incineración de residuos sólidos urbanos, Madrid, Edit. "Cinco Días" (1996).

(14) J.Ma. Rincón, M. Romero, Los materiales vitrocerámicos en la construcción, Materiales de Construcción, Vol. 46 (1996) 242-243, pp. 91-106.

(15) L. Barbieri, L. Bonfatti,A.M. Ferrari, C. Leonelli, T. Manfredini, D. Settembre Blundo, Relationship between microstructure and mechanical properties in fully vitrified stoneware, Ceramics: Charting the Future, Edit. P. Vicenzini, Techna Srl. (1995), pp. 99-105.

(16) A. Escardino, J.L. Amorós, J.E. Enrique, Estudio de pastas de gres para pavimentos, Bol. Soc. Esp. Ceram. Vidr., Vol. 20, n 1 (1981), pp. 17-24.

(17) M. Romero, R.D. Rawlings and J.Ma. Rincón, Development of a New Glass- Ceramic by Means of Controlled Vitrificacion and Crystallisation of Inorganic Wastes from Urban Incineration, J. Eur. Ceram. Soc.,Vol.19 (1999), pp.2049-2058.

(18) J. Ma. Rincón, G.Thomas and J.S. Moya, Microestructural Study of Sintered Mullite Obtained from premullite. Communications for the Americam Ceramic Society C-29, C-31 (1986). 